\title{
Analisis Kesalahan Pengukuran Kecepatan Akibat Distorsi Lensa
}

\author{
Yudha Hardhiyana Putra dan Yusuf Kaelani \\ Jurusan Teknik Mesin, Fakultas Teknologi Industri, Institut Teknologi Sepuluh Nopember (ITS) \\ Jl. Arief Rahman Hakim, Surabaya 60111 Indonesia \\ e-mail:y_kaelani@me.its.ac.id
}

\begin{abstract}
Abstrak-Beberapa penelitian telah dilakukan tentang metode baru pengukuran kecepatan dengan bantuan kamera. Namun, penelitian-penelitian tersebut mengabaikan sifat kamera yang mungkin menghasilkan proyeksi gambar melengkung dari pengambilan suatu objek bidang datar. Dalam dunia fotografi, fenomena tersebut dikenal dengan istilah distorsi. Gambar yang terdistorsi tentunya merugikan jika digunakan sebagai piranti untuk mengukur kecepatan. Hal ini terjadi karena efek distorsi bisa mengurangi tingkat ketepatan pengukuran. Pada penelitian ini dilakukan analisis kesalahan pengukuran kecepatan dengan perekaman video terhadap partikel (kereta api mainan) yang bergerak lurus. Kecepatan partikel ini telah diketahui dan dijaga konstan. Video yang dihasilkan kemudian di-extract menjadi rangkaian gambar. Koordinat-koordinat titik pada rangkaian gambar tersebut merupakan bahan untuk analisis perpindahan. Data perpindahan selanjutnya diolah untuk analisis kecepatan sesaat. Hasil analisis kecepatan sesaat kemudian dibandingkan dengan kecepatan konstan partikel guna mengetahui sejauh mana keakuratan metode penelitian ini. Selain itu, dilakukan juga analisis distorsi untuk mengetahui seberapa besar distorsi yang berlaku pada beberapa focal length. Hasil yang diperoleh dari penelitian ini menunjukkan bahwa tingkat kesalahan pengukuran kecepatan partikel dengan focal length $22 \mathrm{~mm}$ cenderung lebih kecil daripada saat menggunakan focal length $10 \mathrm{~mm}$. Di sisi lain, distorsi lensa yang berlaku pada focal length $22 \mathrm{~mm}$ juga jauh lebih kecil. Maka dapat disimpulkan bahwa distorsi dan tingkat kesalahan memiliki korelasi yang berbanding lurus. Semakin kecil distorsi yang berlaku pada suatu focal length, semakin kecil pula kesalahan pengukuran yang terjadi. Dengan demikian, focal length $22 \mathrm{~mm}$ relatif aman digunakan untuk pengukuran kecepatan dengan bantuan kamera.
\end{abstract}

Kata Kunci-distorsi, focal length, kamera, pengukuran kecepatan, tingkat kesalahan

\section{PENDAHULUAN}

$\mathrm{P}$ ENELITIAN tentang metode baru pengukuran kecepatan telah dilakukan, salah satunya pengukuran kecepatan dengan bantuan kamera. Penelitian-penelitian dengan metode tersebut telah dilakukan oleh Wong Windra Gunawan [1] dan Adi Wahyu Christianto [2]. Pada penelitian yang dilakukan Wong Windra Gunawan, web camera digunakan untuk pengambilan gerakan partikel yang bergerak di atas treadmill. Hasil yang diperoleh berupa serangkaian gambar yang dapat digunakan sebagai alat untuk mengukur kecepatan dan percepatan partikel tersebut. Sedangkan penelitian Adi Wahyu Christianto menggunakan fitur video dari sebuah compact digital camera. Hasil yang didapat berupa file video yang kemudian di-extract dengan software menjadi serangkaian gambar yang berfungsi sama seperti penelitian Wong Windra Gunawan. Namun, kedua penelitian tersebut mengabaikan sifat kamera yang menghasilkan proyeksi melengkung dari pengambilan gambar suatu objek bidang datar. Fenomena tersebut dalam dunia fotografi dikenal dengan istilah distorsi.

Dalam dunia fotografi, efek distorsi bisa menjadi hal yang menguntungkan. Namun, gambar yang terdistorsi tentunya merugikan jika digunakan sebagai piranti untuk mengukur kecepatan. Hal ini disebabkan karena efek distorsi bisa mengurangi tingkat ketepatan pengukuran seiring berubahnya posisi partikel yang menjauh dari bagian tengah gambar. Distorsi yang terjadi pun akan semakin besar seiring semakin pendeknya focal length yang digunakan. Sayangnya, hingga saat ini belum diketahui secara pasti nilai distorsi yang berlaku untuk tiap-tiap focal length.

Tujuan dilakukannya penelitian ini adalah untuk mengetahui tingkat kesalahan (error rate) yang terjadi dalam pengukuran kecepatan dari pengamatan gambar dua dimensi terhadap objek tiga dimensi yang bergerak lurus dengan kecepatan konstan pada suatu bidang datar. Pada penelitian ini dilakukan analisis kecepatan terhadap gerakan kereta api mainan dan distorsi yang terjadi pada focal length $10 \mathrm{~mm}$ dan $22 \mathrm{~mm}$ melalui gambar hasil kamera DSLR.

Hasil penelitian ini dapat digunakan sebagai referensi dalam dunia fotografi dan sarana koreksi terhadap penelitianpenelitian yang menggunakan kamera untuk analisis kinematika.

\section{URAIAN PENELITIAN}

\section{A. Kamera DSLR (Digital Single Lens Reflect)}

Dalam Bahasa Indonesia, kamera DSLR dapat diartikan menjadi kamera digital dengan satu cermin pantul. Cahaya dari objek akan masuk melalui lensa hingga mengenai cermin pantul dan dilanjutkan menuju pentaprisma (cermin segi lima) untuk dipantulkan beberapa kali hingga menyentuh viewfinder atau pembidik. Ketika tombol shutter dilepaskan, cermin pantul akan mengayun ke atas sehingga cahaya mengenai image sensor. Sensor pada kamera DSLR berfungsi sama dengan lempengan film pada kamera konvensional. Lempengan film memiliki standar ukuran, yaitu $24 \mathrm{~mm} \times 36 \mathrm{~mm}$, yang disebut sebagai $35 \mathrm{~mm}$ format. Namun, ukuran image sensor pada kamera digital tidak terstandardisasi. Sehingga kamera DSLR yang mempunyai ukuran image sensor $24 \mathrm{~mm} \times 36 \mathrm{~mm}$ disebut kamera DSLR Full-frame. Sedangkan kamera DSLR dengan 
image sensor yang lebih kecil disebut kamera DSLR Crop.

Pada kamera DSLR Full-frame, gambar yang dihasilkan akan sesuai dengan apa yang tertangkap oleh kamera. Sedangkan pada kamera DSLR Crop, gambar yang dihasilkan akan mengalami pemotongan sebesar crop factor yang berlaku, seperti yang tampak pada Gambar 1.

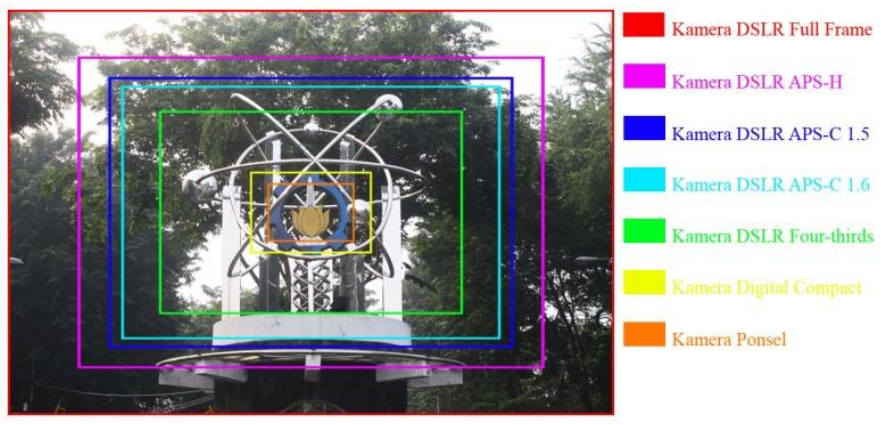

Gambar 1. Crop Factor pada Beberapa Jenis Kamera

Kamera DSLR yang digunakan pada penelitian ini adalah tipe APS-C dengan crop factor 1,6. Crop factor menyebabkan sudut pandang (angle of view) pengambilan gambar menjadi lebih sempit. Sehingga dengan focal length yang pendek, gambar yang dihasilkan seakan-akan diambil dengan focal length yang lebih panjang. Inilah yang disebut sebagai equivalent focal length, yang dapat dirumuskan sebagai berikut.

$$
f_{e}=f x \text { crop factor }
$$

Secara umum, lensa kamera DSLR dibagi menjadi dua, yaitu lensa prime atau fix dan lensa zoom. Lensa prime adalah lensa yang memiliki focal length tetap, misalnya $50 \mathrm{~mm}, 85 \mathrm{~mm}$, dan $100 \mathrm{~mm}$. Sedangkan lensa zoom adalah lensa yang memungkinkan perubahan nilai focal length sesuai kebutuhan, misalnya 18-55 mm, 17-85 mm, dan sebagainya. Lensa zoom bahkan ada yang dirancang mampu mengakomodasi aplikasi wide-angle hingga telephoto, misalnya lensa $24-300 \mathrm{~mm}$. Pada lensa zoom, terdapat istilah optical zoom, yaitu perbandingan antara zoom-out dan zoom-in maksimum. Maka pada lensa 24$300 \mathrm{~mm}$, nilai optical zoom yang berlaku adalah 300:24 atau 12,5 kali.

Suatu peralatan yang memiliki elemen lensa, salah satunya kamera, tentunya sangat rentan terhadap pengaruh distorsi. Distorsi adalah suatu fenomena ketidakakuratan lensa dalam menangkap suatu citra akibat melengkungnya optik sehingga gambar yang dihasilkan juga mengalami lengkungan di bagian tepi.
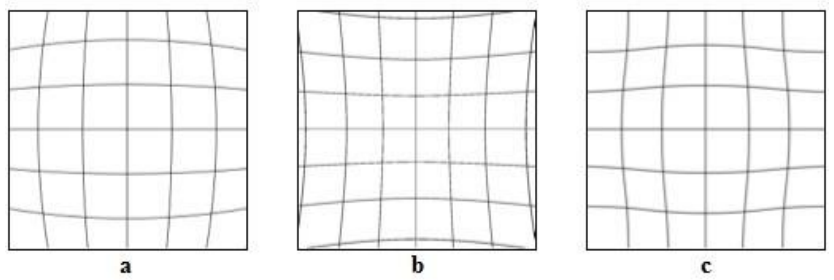

Gambar 2. Penampakan Distorsi (a) Barrel, (b) Pincushion, dan (c) Mustache

Gambar 2 memperlihatkan bahwa efek distorsi menyebabkan suatu garis yang lurus menjadi tampak melengkung dan dapat terjadi pada lensa wide-angle dan telephoto. Distorsi pada lensa wide-angle disebut distorsi barrel, karena bentuknya menyerupai tong yang membesar di bagian tengahnya. Sedangkan distorsi pada lensa telephoto disebut distorsi pincushion, kebalikan dari distorsi barrel, mengecil pada bagian tengah. Selain dua jenis tersebut, terdapat juga distorsi mustache. Distorsi yang dinamakan karena bentuknya menyerupai kumis ini tidak terlalu populer walaupun pada praktiknya cukup sering terjadi. Distorsi mustache merupakan kombinasi dari distorsi barrel dan pincushion sehingga sering disebut sebagai distorsi kompleks. Distorsi ini biasanya terjadi pada lensa dengan nilai optical zoom yang besar, misalnya lensa 24-300 mm (optical zoom 12,5 kali). Pada aplikasi zoom-out maksimum, distorsi mustache tersusun atas distorsi barrel pada bagian tengah dan distorsi pincushion pada bagian tepi. Sedangkan pada zoom-in maksimum, komposisi berubah menjadi distorsi pincushion di bagian tengah dan distorsi barrel pada bagian tepi. Penelitian ini hanya melibatkan distorsi barrel karena pengambilan video dilakukan menggunakan lensa wideangle dengan nilai optical zoom sebesar 2,2 kali.

\section{B. Transformasi Rotasi Tiga Dimensi}

Transformasi rotasi adalah perubahan suatu titik koordinat menuju kedudukan baru dengan menggerakkan titik tersebut sesuai nilai besaran sudut pada suatu sumbu putar. Suatu titik koordinat tiga dimensi yang ditentukan oleh tiga posisi, yaitu posisi terhadap sumbu $\mathrm{X}$, sumbu $\mathrm{Y}$, dan sumbu $\mathrm{Z}$, dapat dirotasikan dalam bentuk operasi matriks. Pada penelitian ini, transformasi rotasi dapat digunakan untuk mencari nilai distorsi lensa pada titik-titik yang diinginkan. Rotasi suatu titik pada sistem koordinat tiga dimensi dapat dilakukan terhadap sumbu $\mathrm{X}$, sumbu Y, maupun sumbu Z. Objek pada penelitian ini dikondisikan bergerak pada sumbu $X$, sedangkan gerakan pada sumbu Y dan Z sangat kecil sehingga dapat diabaikan. Oleh karena itu, transformasi rotasi yang dilakukan hanya terhadap sumbu Y saja.

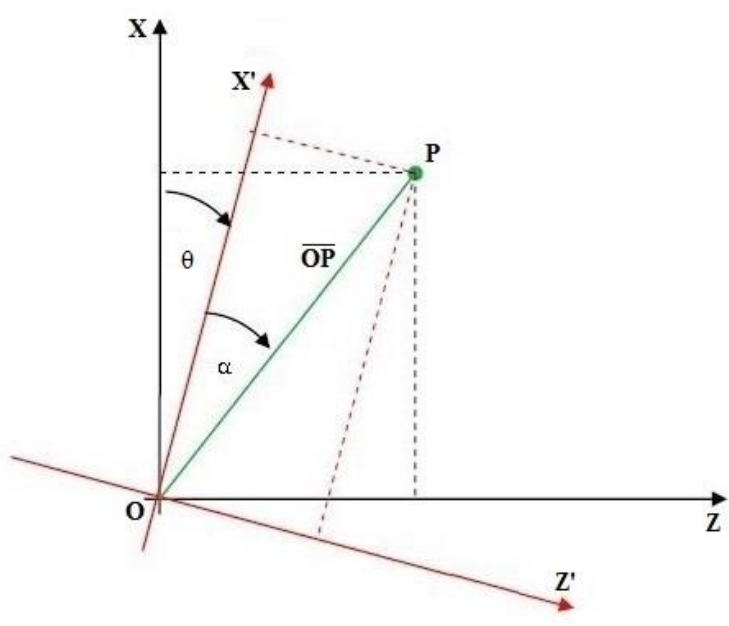

Gambar 3. Rotasi Searah Jarum Jam terhadap Sumbu Y

Gambar 3 menunjukkan bagaimana suatu titik dirotasikan sebesar $\theta$ terhadap sumbu Y. Adapun rumus untuk mendapatkan koordinat baru dari proses rotasi tersebut adalah sebagai berikut. 


$$
\left[\begin{array}{l}
x^{\prime}{ }_{p} \\
y_{p}^{\prime} \\
z_{p}^{\prime}
\end{array}\right]=\left[\begin{array}{ccc}
\cos \theta & 0 & \sin \theta \\
0 & 1 & 0 \\
-\sin \theta & 0 & \cos \theta
\end{array}\right]\left[\begin{array}{l}
x_{p} \\
y_{p} \\
z_{p}
\end{array}\right]
$$

\section{Prosedur Penelitian}

Langkah-langkah yang benar dan sistematis diperlukan untuk mencapai tujuan penelitian. Mengingat penelitian ini diharapkan bisa bermanfaat sebagai koreksi terhadap penelitian-penelitian terdahulu, serta sebagai referensi untuk penelitian-penelitian berikutnya dan informasi bagi dunia fotografi, kondisi dan metode perekaman video sangat diperhatikan.

\section{Mengatur Focal length}

Setelah peralatan dalam kondisi siap pakai, hal pertama yang perlu dilakukan ialah mengatur focal length. Focal length dapat diatur dengan memutar grip pada lensa. Putaran searah jarum jam (clockwise) untuk memperpendek focal length dan putaran berlawanan arah jarum jam (counterclockwise) untuk sebaliknya.

\section{Mengatur Tata Letak Peralatan}

Pada pengambilan dekat, jarak $(d)$ antara kamera dan objek adalah $9 \mathrm{~cm}$ untuk focal length $10 \mathrm{~mm}$ dan 29,4 untuk focal length $22 \mathrm{~mm}$. Sedangkan pada pengambilan jauh, jarak $(d)$ antara kamera dan objek dua kali lipat jarak (d) pada pengambilan dekat.

\section{Merekam Video}

Perekaman video dilakukan selama kereta api mainan bergerak melewati frame dengan tiga repetisi untuk gerakan konstan jarak dekat dan dua kali untuk gerakan konstan jarak jauh, serta sekali untuk gerakan dengan perlambatan.

4. Mengekstraksi Video

Setelah file video diperoleh, langkah selanjutnya adalah mengekstraksi, yaitu memecah video menjadi rangkaian gambar, dengan mengoperasikan software Blender. Rangkaian gambar adalah gambar-gambar yang saling berurutan. Jumlah gambar yang dihasilkan bergantung dari frame rate dan durasi video.

5. Menganalisis Gambar

Ada tiga nilai yang dicari melalui analisis gambar, yaitu:

a. Skala (pixel/cm)

Meletakkan mistar tepat di tengah dan sejajar dengan kamera bertujuan agar proyeksi mistar tidak mengalami distorsi secara vertikal. Selain itu, untuk menghindari distorsi secara horizontal, satuan panjang yang digunakan sebagai skala adalah $1 \mathrm{~cm}$ pada bagian tengah mistar sehingga konversi dari pixel ke $\mathrm{cm}$ ataupun sebaliknya dapat lebih akurat.

b. Kecepatan Universal, $\tilde{\mathrm{V}}_{u}$ (pixel/detik)

$$
\tilde{\mathrm{V}}_{u}=\frac{w \cdot \text { frame rate }}{N}
$$

c. Koordinat Posisi

6. Menganalisis Perpindahan

Frame pertama menghasilkan koordinat $\left(\mathrm{x}_{1}, \mathrm{y}_{1}\right)$. Frame kedua menghasilkan koordinat $\left(\mathrm{x}_{2}, \mathrm{y}_{2}\right)$, dan demikian selanjutnya hingga frame terakhir. Dengan demikian, nilai perpindahan secara horizontal $(\Delta \mathrm{x})$ adalah sebagai berikut.

$$
\overrightarrow{\Delta x_{n}}=x_{n+1}-x_{n}
$$

Sedangkan nilai perpindahan secara vertikal $(\Delta y)$ adalah sebagai berikut.

$$
\overrightarrow{\Delta y_{n}}=y_{n+1}-y_{n}
$$

7. Menganalisis Kecepatan Sesaat, $\tilde{V}_{n}$ (pixel/detik)

Kecepatan sesaat adalah kecepatan objek dalam waktu yang sangat singkat. Dalam penelitian ini, kecepatan sesaat adalah kecepatan objek antar frame dalam interval tertentu, yang dapat dirumuskan sebagai berikut.

$$
\tilde{\mathrm{V}}_{n}=\frac{\sqrt{\Delta x_{n}{ }^{2}+\Delta y_{n}{ }^{2}} \cdot \text { frame rate }}{\text { Interval }}
$$

8. Membandingkan Kecepatan $\mathrm{Z}_{0}$ dan Sesaat $\left(\tilde{V}_{n}\right)$

Hal ini dilakukan untuk mengetahui seberapa besar pengaruh distorsi lensa terhadap keakuratan pengukuran kecepatan. Kereta api yang bergerak dengan kecepatan konstan seharusnya memiliki kecepatan sesaat yang sama, baik pada bagian tengah ataupun tepi frame. Hal tersebut dikarenakan tidak adanya percepatan yang terjadi. Namun, suatu distorsi bisa menyebabkan terjadinya selisih kecepatan sesaat antara bagian tengah dan tepi frame, yang dapat dianggap sebagi error. Tingkat kesalahan (error rate) tersebut dapat dirumuskan sebagai berikut.

$$
E=\frac{\left|\tilde{\mathrm{V}}_{n}-\tilde{\mathrm{V}}_{Z_{0}}\right|}{\tilde{\mathrm{V}}_{Z_{0}}} \cdot 100 \%
$$

9. Menganalisis Percepatan Sesaat, $\tilde{a}_{n}$ (pixel/detik ${ }^{2}$ )

Percepatan sesaat adalah perubahan kecepatan objek dalam waktu yang sangat singkat. Dalam penelitian ini, percepatan sesaat adalah perubahan kecepatan objek antar frame dalam interval tertentu, yang dapat dirumuskan sebagai berikut.

$$
\tilde{a}_{n}=\frac{\left(\tilde{\mathrm{V}}_{n+1}-\tilde{\mathrm{V}}_{n}\right) \cdot \text { frame rate }}{\text { Interval }}
$$

10. Mengonversi Nilai $d$ dari cm ke pixel

Skala yang diperoleh melalui analisis gambar akan digunakan untuk mengonversi nilai jarak $(d)$ antara kamera dan objek dari cm ke pixel. Hasil konversi dalam satuan pixel akan digunakan untuk nilai $\mathrm{z}_{0}$.

11. Menganalisis Distorsi

Langkah pertama dalam analisis distorsi adalah menentukan posisi 0 (nol). Langkah berikutnya adalah menentukan posisiposisi yang ingin diketahui distorsinya, misalnya di titik a. Kemudian dilanjutkan dengan mencari sudut $\theta$ dengan rumus berikut.

$$
\theta_{a}=\tan ^{-1} \frac{\left|x_{0}-x_{a}\right|}{z_{0}}
$$

Langkah keempat adalah mencari koordinat baru dengan melakukan transformasi rotasi sebesar $\theta$ terhadap sumbu Y dengan cara berikut.

$$
\left[\begin{array}{l}
x_{a}{ }^{\prime} \\
y_{a}{ }^{\prime} \\
z_{a}{ }^{\prime}
\end{array}\right]=\left[\begin{array}{ccc}
\cos \theta & 0 & \sin \theta \\
0 & 1 & 0 \\
-\sin \theta & 0 & \cos \theta
\end{array}\right]\left[\begin{array}{l}
x_{a} \\
y_{a} \\
z_{a}
\end{array}\right]
$$

Sehingga distorsi yang terjadi pada titik a dapat dicari dengan rumus berikut.

$$
\Delta z_{a}=z_{a}{ }^{\prime}-z_{0}
$$


Setelah diketahui nilai distorsi pada titik a, maka persentase distorsi dapat dicari dengan rumus berikut.

$$
\text { Persentase Distorsi }=\frac{\Delta z_{a}}{z_{a^{\prime}}} \cdot 100 \%
$$

\section{HASIL DAN DISKUSI}

\section{A. 10,1245 Skala}

Nilai skala didapatkan melalui pengamatan gambar mistar. Suatu mistar kayu yang terlihat jelas satuan sentimeternya diletakkan secara horizontal, seperti pada Gambar 4, sehingga dapat diketahui jumlah pixel yang terwakili oleh jarak satu sentimeter tersebut.

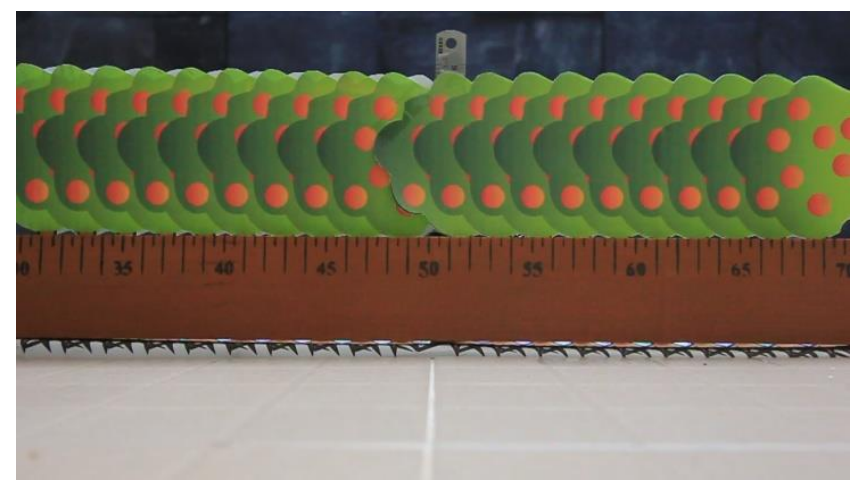

Gambar 4. Mistar Kayu dalam Posisi Horizontal

Nilai skala diambil dari jarak satu sentimeter mistar yang berada tepat di tengah frame karena bagian tersebut diyakini tidak mengalami distorsi. Tabel 1 berikut menyajikan nilai skala yang berlaku untuk variasi jarak tiap focal length.

Tabel 1.

Faktor Skala

\begin{tabular}{ccccc}
\hline \hline $\begin{array}{c}\text { Focal } \\
\text { Length }\end{array}$ & Kondisi & Kode & $\begin{array}{c}\text { Jarak Kamera } \\
(\mathrm{cm})\end{array}$ & $\begin{array}{c}\text { Skala } \\
(\text { pixel/cm) }\end{array}$ \\
\hline \multirow{2}{*}{$10 \mathrm{~mm}$} & Dekat & Co & 9 & 34 \\
& Jauh & Cf & 18 & 23 \\
\multirow{2}{*}{$22 \mathrm{~mm}$} & Dekat & Co & 29,4 & 33 \\
& Jauh & Cf & 58,8 & 20 \\
\hline
\end{tabular}

B. Kecepatan Universal $\left(\tilde{\mathrm{V}}_{u}\right)$

Perekaman video terhadap objek (kereta api mainan) yang bergerak konstan dilakukan sebanyak tiga kali dari jarak dekat dan dua kali dari jarak jauh untuk masing-masing focal length. Perekaman dilakukan lebih dari satu kali untuk memastikan apakah objek memang bergerak dengan kecepatan konstan. Sedangkan pengambilan dekat dan jauh dilakukan untuk mendapatkan informasi apakah variasi jarak memiliki pengaruh yang berarti. Pengamatan kemudian dilakukan pada rangkaian gambar hasil ekstraksi video-video tersebut. Tabel 2 berikut adalah data kecepatan universal objek yang direkam dengan focal length $10 \mathrm{~mm}$.

Tabel 2.

Data Kecepatan Universal pada Focal length $10 \mathrm{~mm}$

\begin{tabular}{cccccccc}
\hline \hline Video & $\begin{array}{c}\text { Frame } \\
\text { awal }\end{array}$ & $\begin{array}{c}\text { Frame } \\
\text { akhir }\end{array}$ & $\begin{array}{c}\text { Batas } \\
\text { kanan }\end{array}$ & $\begin{array}{c}\text { Batas } \\
\text { kiri }\end{array}$ & $\begin{array}{c}\mathrm{V} \mu \\
\text { (pixel/s) }\end{array}$ & Skala & $\begin{array}{c}\mathrm{V} \mu \\
(\text { pixel/cm) }\end{array}$ \\
\hline Co1 & 188 & 410 & 1272 & 4 & 340,8248 & & 10,0243 \\
Co2 & 203 & 425 & 1271 & 5 & 340,2872 & 34 & 10,0084 \\
Co3 & 218 & 440 & 1272 & 3 & 341,0935 & & 10,0322 \\
\hline \hline
\end{tabular}

\begin{tabular}{lllllllc}
\hline \hline CF1 & 314 & 544 & 1068 & 191 & 227,5644 & \multirow{2}{*}{23} & 9,8941 \\
CF2 & 299 & 524 & 1069 & 191 & 232,8642 & & 10,1245 \\
\hline \hline
\end{tabular}

Sedangkan data kecepatan universal objek pada focal length $22 \mathrm{~mm}$ tersaji pada Tabel 3 berikut.

Tabel 3.

Data Kecepatan Universal pada Focal length $22 \mathrm{~mm}$

\begin{tabular}{lccccccc} 
Video & $\begin{array}{c}\text { Frame } \\
\text { awal }\end{array}$ & $\begin{array}{c}\text { Frame } \\
\text { akhir }\end{array}$ & $\begin{array}{c}\text { Batas } \\
\text { kanan }\end{array}$ & $\begin{array}{c}\text { Batas } \\
\text { kiri }\end{array}$ & $\begin{array}{c}\text { V } \mu \\
\text { (pixel/s) }\end{array}$ & Skala & $\begin{array}{c}\text { V } \mu \\
\text { (pixel/cm) }\end{array}$ \\
\hline Co4 & 180 & 434 & 1274 & 8 & 297,5845 & & 9,0177 \\
Co5 & 156 & 408 & 1272 & 9 & 299,2262 & 33 & 9,0675 \\
Co6 & 170 & 422 & 1272 & 10 & 298,9892 & & 9,0603 \\
CF3 & 304 & 577 & 1028 & 207 & 179,6012 & 20 & 8,9801 \\
CF4 & 283 & 553 & 1026 & 207 & 181,1471 & & 9,0574 \\
\hline
\end{tabular}

Jika dilakukan perbandingan data antara kedua focal length, tabel-tabel di atas menunjukkan adanya perbedaan kecepatan universal yang signifikan, yaitu sekitar $1 \mathrm{~cm} / \mathrm{s}$. Namun, baik pada focal length $10 \mathrm{~mm}$ maupun $22 \mathrm{~mm}$, kondisi pengambilan dekat dan jauh menunjukkan selisih nilai kecepatan universal yang relatif kecil. Pada focal length $10 \mathrm{~mm}$, selisih kecepatan universal untuk pengambilan jarak dekat dan jauh sekitar 0.1 $\mathrm{cm} / \mathrm{s}$ (1\%). Sedangkan pada focal length $22 \mathrm{~mm}$, selisihnya hanya sekitar $0.03 \mathrm{~cm} / \mathrm{s}(0.33 \%)$. Hal tersebut membuktikan bahwa objek memang bergerak dengan kecepatan konstan dan variasi jarak pengambilan video tidak memiliki pengaruh yang berarti terhadap analisis kecepatan universal. Namun, pengukuran kecepatan dengan focal length yang berbeda bisa memberikan hasil pengamatan yang berbeda pula.

\section{Perbandingan Tingkat Kesalahan}

Pada bagian ini akan dibandingkan pengaruh focal length 10 $\mathrm{mm}$ dan $22 \mathrm{~mm}$ terhadap metode pengukuran kecepatan konstan dengan bantuan kamera DSLR.

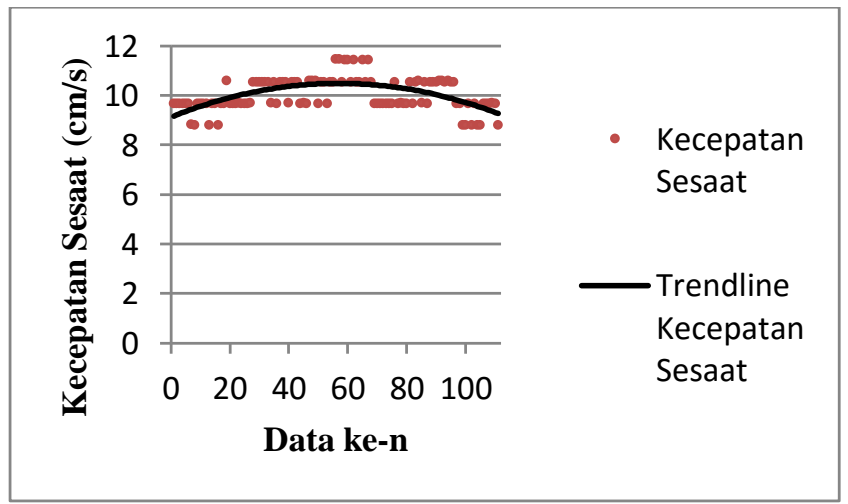

Gambar 5. Grafik Kecepatan Sesaat Konstan-Dekat pada Focal length $10 \mathrm{~mm}$

Gambar 5 menunjukkan adanya selisih kecepatan sesaat antara bagian tengah dan tepi frame pada perekaman gerakan objek berkecepatan konstan jarak dekat dengan focal length 10 $\mathrm{mm}$. Selisih kecepatan sesaat tersebut bernilai sekitar $1.8 \mathrm{~cm} / \mathrm{s}$ (15.63\%). Trendline juga menunjukkan seolah-olah terjadi peningkatan kecepatan pada pada bagian tengah, kemudian terjadi penurunan kecepatan hingga bernilai seperti sedia kala. 


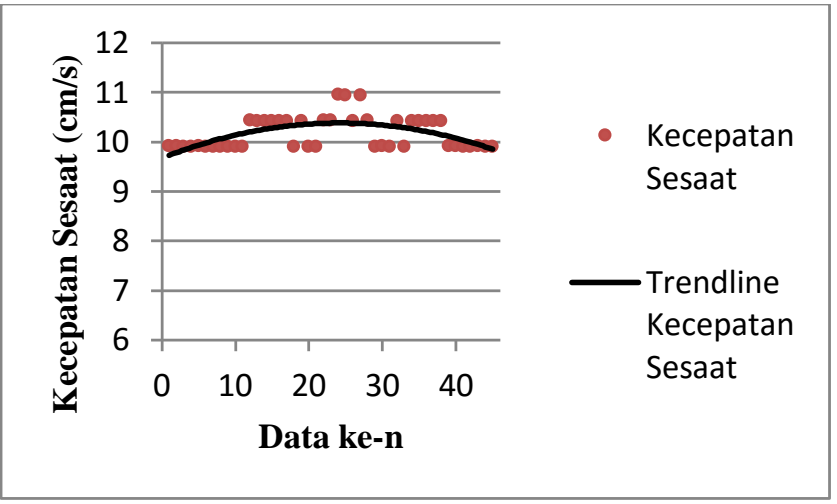

Gambar 6. Grafik Kecepatan Sesaat Konstan-Jauh pada Focal length $10 \mathrm{~mm}$

Gambar 6 menunjukkan adanya selisih kecepatan sesaat antara bagian tengah dan tepi frame pada perekaman gerakan objek berkecepatan konstan jarak jauh dengan focal length 10 $\mathrm{mm}$. Selisih kecepatan sesaat tersebut bernilai sekitar $1 \mathrm{~cm} / \mathrm{s}$ (9.5\%). Trendline juga menunjukkan hal yang sama seperti pada Gambar 5. Hal ini membuktikan bahwa jarak pengambilan video tidak berpengaruh pada karakteristik suatu focal length, karena baik pada pengambilan jarak dekat maupun jauh terjadi distribusi data yang serupa.

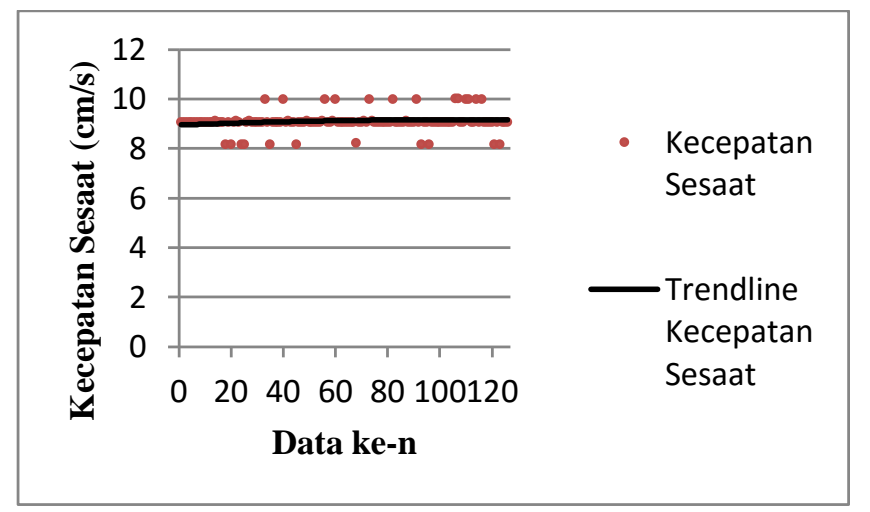

Gambar 7. Grafik Kecepatan Sesaat Konstan-Dekat pada Focal length $22 \mathrm{~mm}$

Gambar 7 menunjukkan nilai kecepatan sesaat yang relatif homogen pada perekaman gerakan objek berkecepatan konstan jarak dekat dengan focal length $22 \mathrm{~mm}$, yaitu sebesar $9.08 \mathrm{~cm} / \mathrm{s}$. Walaupun beberapa data memiliki nilai yang lebih tinggi dan lebih rendah, trendline membentuk garis linear yang menunjukkan bahwa focal length $22 \mathrm{~mm}$ relatif aman dari pengaruh distorsi.

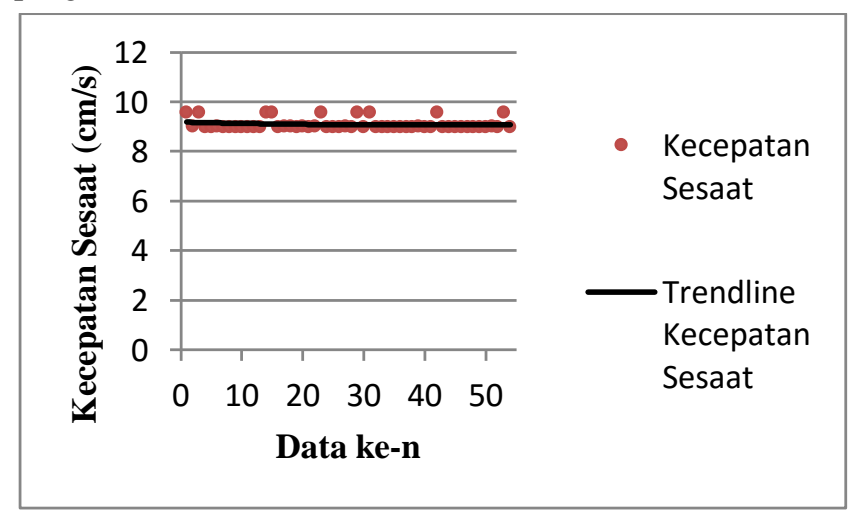

Gambar 8. Grafik Kecepatan Sesaat Konstan-Jauh pada Focal length $22 \mathrm{~mm}$
Gambar 8 menunjukkan bahwa nilai kecepatan sesaat pada perekaman gerakan objek berkecepatan konstan jarak jauh dengan focal length $22 \mathrm{~mm}$ cenderung seragam, yaitu sebesar $8.99 \mathrm{~cm} / \mathrm{s}$. Walaupun terdapat beberapa data yang bernilai lebih tinggi, trendline membentuk garis yang serupa seperti pada Gambar 7.

Jika dilakukan perbandingan antara kedua focal length, 22 $\mathrm{mm}$ (ekivalen $35 \mathrm{~mm}$ ) tentunya lebih aman daripada $10 \mathrm{~mm}$ (ekivalen $16 \mathrm{~mm}$ ) jika digunakan sebagai focal length untuk mengukur kecepatan partikel. Hal tersebut karena efek distorsi sangat kecil terhadap hasil perekaman video dengan focal length $22 \mathrm{~mm}$.

\section{Perbandingan Distorsi}

Pada bagian ini dijelaskan bagaimana bentuk distorsi yang terjadi pada focal length 10 dan $22 \mathrm{~mm}$.

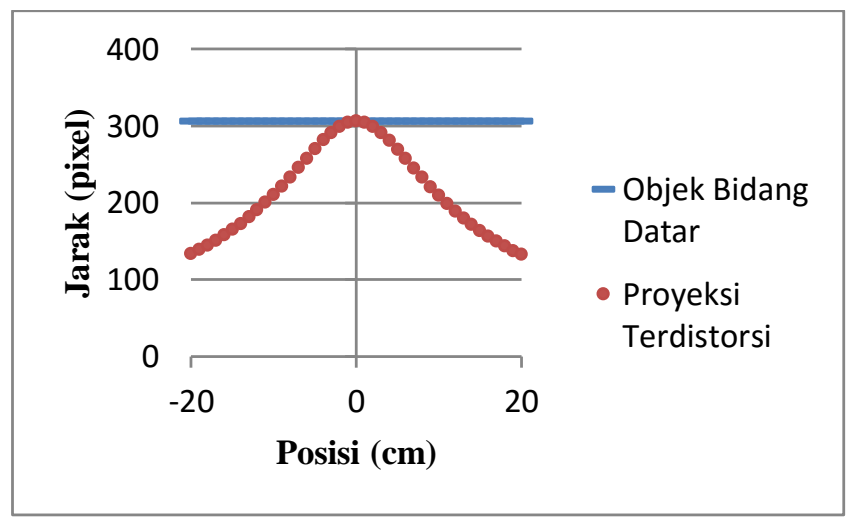

Gambar 9. Proyeksi Distorsi pada Focal length $10 \mathrm{~mm}$

Gambar 9 menunjukkan bagaimana distorsi pada focal length $10 \mathrm{~mm}$ terjadi. Proyeksi distorsi focal length $10 \mathrm{~mm}$ membentuk kurva yang tajam. Berdasarkan hasil analisis data, sudut (angle of view) yang dibentuk oleh focal length $10 \mathrm{~mm}$ adalah sekitar $128^{\circ}$ dan distorsi pada bagian tepi mencapai $56 \%$.

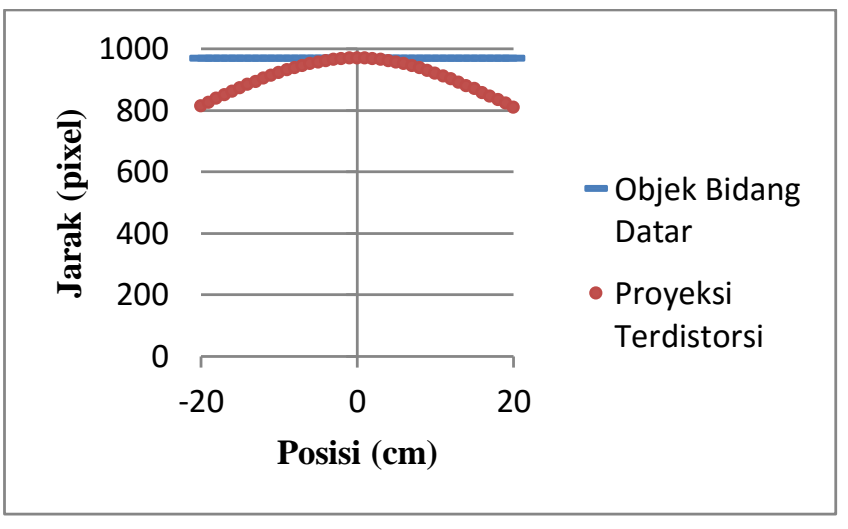

Gambar 10. Proyeksi Distorsi pada Focal length $22 \mathrm{~mm}$

Gambar 10 menunjukkan bagaimana distorsi pada focal length $22 \mathrm{~mm}$ terjadi. Proyeksi distorsi focal length $22 \mathrm{~mm}$ membentuk kurva yang jauh lebih landai. Berdasarkan hasil analisis data, sudut (angle of view) yang dibentuk oleh focal length $22 \mathrm{~mm}$ adalah sekitar $66^{\circ}$ dan distorsi pada bagian tepi hanya $16 \%$.

\section{E. Pemodelan Efek Distorsi}

Sistem koreksi otomatis suatu lensa menyebabkan 
berkurangnya efek distorsi terhadap hasil pengambilan gambar dan/atau perekaman video. Oleh karena itu, pada bagian ini akan dijelaskan suatu pemodelan efek distorsi. Langkahlangkah dalam memodelkan efek distorsi tersebut adalah:

1. Merancang rumus efek distorsi (B)

$$
B=\sqrt{\left(2 A^{2}+A^{2} \cdot \operatorname{Tan}^{2}(\theta)-2 A^{2} \sqrt{1+\operatorname{Tan}^{2}(\theta)}\right)}
$$

2. Menggambar grafik efek distorsi sebagai fungsi posisi

3. Membatasi bidang pengamatan pada posisi -10 sampai dengan 10

4. Melakukan operasi eksponensial terhadap rumus efek distorsi hingga ditemukan profil grafik yang menyerupai trendline kecepatan sesaat gerakan objek dengan kecepatan konstan

Gambar 5 dan Gambar 6 menunjukkan trendline kecepatan sesaat pada focal length $10 \mathrm{~mm}$ membentuk kurva. Hal tersebut terjadi karena kecepatan sesaat pada bagian tepiframe memiliki nilai yang lebih rendah daripada bagian tengah. Kurva tersebut juga dapat dianggap sebagai pendekatan efek distorsi yang terjadi pada focal length $10 \mathrm{~mm}$. Dengan melakukan trial and error berupa operasi eksponensial terhadap rumus efek distorsi (B), maka diperoleh suatu angka eksponensial (e) yang menyebabkan profil efek distorsi menyerupai kurva yang terdapat pada Gambar 5 dan 6. Profil efek distorsi berpangkat $\left(\mathrm{B}^{\mathrm{e}}\right)$ dengan angka eksponensial (e) sebesar 1,3 tersaji pada Gambar 11 berikut.

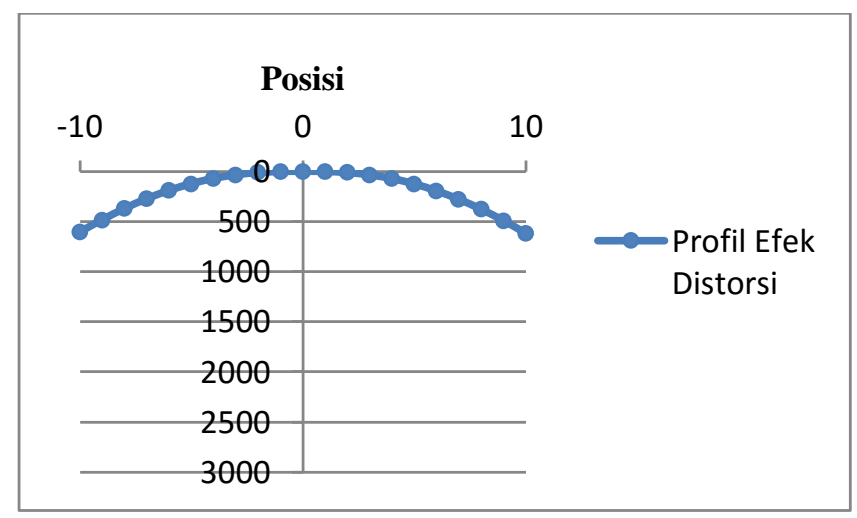

Gambar 11. Profil Efek Distorsi Focal length 10 mm (e = 1.3)

Gambar 7 dan Gambar 8 menunjukkan trendline kecepatan sesaat pada focal length $22 \mathrm{~mm}$ membentuk garis linear. Hal tersebut terjadi karena kecepatan sesaat pada bagian tengah dan tepi frame memiliki nilai yang sama. Garis linear tersebut juga dapat dianggap sebagai pendekatan efek distorsi yang terjadi pada focal length $22 \mathrm{~mm}$. Dengan melakukan trial and error berupa operasi eksponensial terhadap rumus efek distorsi (B), maka diperoleh suatu angka eksponensial (e) yang menyebabkan profil efek distorsi menyerupai garis linear yang terdapat pada Gambar 7 dan 8. Profil efek distorsi berpangkat $\left(\mathrm{B}^{\mathrm{e}}\right)$ dengan angka eksponensial (e) sebesar 2,7 tersaji dalam Gambar 12 berikut.

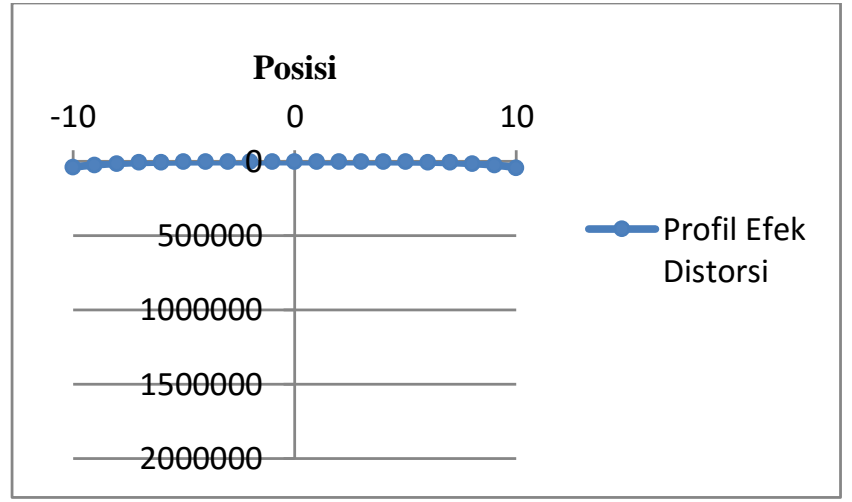

Gambar 12. Profil Efek Distorsi Focal length $22 \mathrm{~mm}(\mathrm{e}=2.7)$

\section{KESIMPULAN}

Hasil penelitian ini dapat dirangkum menjadi beberapa poin, antara lain:

1. Sebagian besar data pengukuran kecepatan konstan pada focal length $10 \mathrm{~mm}$ menunjukkan tingkat kesalahan relatif sebesar $15 \%$, sedangkan pada focal length $22 \mathrm{~mm}$ sebesar $0 \%$. Hal ini membuktikan bahwa efek distorsi pada focal length $10 \mathrm{~mm}$ masih cukup besar, sedangkan pada focal length $22 \mathrm{~mm}$ hampir tidak ada.

2. Distorsi yang berlaku pada focal length $10 \mathrm{~mm}$ mencapai $56 \%$ pada bagian tepi dan membentuk sudut sekitar $128^{\circ}$. Sedangkan pada focal length $22 \mathrm{~mm}$ hanya $16 \%$ dan sudut yang terbentuk sekitar $66^{\circ}$.

3. Penelitian serupa sebaiknya dilakukan menggunakan focal length yang termasuk dalam kategori normal (ekivalen 35-80 $\mathrm{mm}$ ) karena baik hasil pengambilan gambar ataupun perekaman video relatif aman dari efek distorsi.

\section{DAFTAR PUSTAKA}

[1] Gunawan, Wong Windra. 2009. Rancang Bangun Software untuk Mengukur Kecepatan dan Percepatan Sebuah Partikel dengan Online Web Camera. Surabaya. Tugas Akhir. Jurusan Teknik Mesin, Fakultas Teknologi Industri, Institut Teknologi Sepuluh Nopember.

[2] Christianto, Adi Wahyu, dan Kaelani, Yusuf. 2013. Mengukur Kecepatan dan Percepatan Gerak Kaki Manusia Menggunakan Kamera Digital. Surabaya. Jurnal Teknik. Jurusan Teknik Mesin, Fakultas Teknologi Industri, Institut Teknologi Sepuluh Nopember. 